\title{
High-speed railway: impact on regional territorial configurations
}

\author{
A. de Meer \& C. Ribalaygua \\ Departamento de Geografia, Urbanismo y Ordenación del Territorio, \\ University of Cantabria, Spain
}

\begin{abstract}
In contrast to the improvement in accessibility of the cities with H-SR stations, there are greater problems for the connection of the stations with rural areas, making previous experience of connection of the high-speed network with regional transport services especially interesting. To do so, we will attempt to get to know the experiences in the reorganization of regional transport after the arrival of the high-speed railway in low population density areas, through the French cases of Brittany, Rhône-Alpes and Vendôme.

As a hypothesis, we will focus on demonstrating that better exploitation of the infrastructure depends on the characteristics of the high-speed train itself, and especially on the actions and strategies developed around it. In other words, there should be a project for restructuring the regional transport model, in which all those involved should develop a coordinated strategy.
\end{abstract}

Keywords: high-speed rail, reorganization of regional transport, accessibility, intermodality.

\section{Introduction}

The contributions about the effects of the H-SR have enabled an in-depth study of the scientific knowledge about models of localization (Ureña and Ribalaygua [1]), territorial changes (Ureña et al. [2]), economic processes (De Meer [3]) and urban dynamics (AAVV [4] and Bellet [5]). In this context, the transformations provoked by the H-SR in rural areas and the models of penetration of the flows in low population density areas will be considered, given that it is of particular interest to be able to analyze the measures that contribute in increasing the capacity to publicize the accessibility of the high-speed railway on the regional 
scale. The starting premise is to consider that there are very relevant activities such as second homes, uses related to the enjoyment of nature or small disperse population nuclei, whose accessibility to the benefits of the H-SR constitute an opportunity.

In contrast to the improvement in accessibility of the cities that have H-SR, there are greater problems to connect the stations to rural areas, which make the experiences of connection of the high-speed network with the regional transport services especially relevant (Garmendia et al. [6]). The experience in reorganizing regional transport after the arrival of the high-speed railway to low population density areas will be studied through the French cases of Brittany, Rhône-Alpes and Vendôme.

As a hypothesis, we will focus on demonstrating that better exploitation of the infrastructure depends on the characteristics of the high-speed train itself, and especially on the actions and strategies developed around it. In other words, there should be a project for restructuring the regional transport model, in which all those involved should carry out coordinated action.

The arrival of the H-SR to a region brings about the revision of the transport model, with the aims of achieving greater publicity of the benefits, enabling the access of all the regional population and of avoiding limitation of its effects to urban areas (Rodríguez Bugarín et al. [7]). To achieve these aims, different systems have been set up, some relying on railways and others creating new management and organization of the different types of transport, in order to connect the high-speed railway to the rest of the transport networks. In this context, intermodality appears to be the best way of connecting the high-speed railway to the low population density areas, through connection with conventional trains, the public bus service or transport on demand (Ribalaygua and De Meer [8]).

\section{Models of penetration of the high-speed railway in low population density areas in France}

The models of penetration of the high-speed railway have been studied through the French cases of Brittany, Rhônes-Alpes and Vendôme. The first of them is Brittany, specifically in the Rennes urban area and the Saint Brieuc region. In reality, from the city of Rennes the penetration of the TGV goes along the coast (Lamballe, St. Brieuc, St. Malo, Lannion, Brest, Quimper, Lorient, Vannes and Redon), completed with regional railway lines (TER) towards the interior and a TER bus network that links different routes, with the addition of two regional bus lines (Rennes-Loudéac, Rennes-Pontivy). This system enables good communication and coordination of timetables among the train stations, regional buses and the stations with TGV stops (Rennes Métropole [9]). Therefore, the TGV only gets to specific points and the penetration is provided by the trains and buses (TER and regional), which use combined tickets that are controlled by SNCF in the case of the TER lines. Private cars are also used, especially in the central rural areas. The strategy followed is "to get one of your important cities to be used as a TGV stop and at the same time improve the regional transport 
system so as to communicate the rest of the cities in the region with this node with journey times of less than one hour" (Rodriguez Bugarin, 2005 (7)).

The coastal Saint-Brieuc region is connected via two stations (Lamballe and Saint Brieuc) guaranteeing a significant number of TGV to Paris and Rennes, which enables the Saint Brieuc service to be used by around 2,800 people per day. The TGV penetration in this area of Brittany is aided by a strong regional train support. Moreover, the SCOT - Schéma de Cohérence Territorialeprogramme promotes the construction of car parks at the train stations with TER services, with the aim of increasing the usage as a communication means between different population nuclei.

All this must be completed with another type of offer, given that it is a rural zone with a very disperse territorial model where; there are many journeys, it is not part of the large infrastructures, there are people without cars or that are elderly and where there is a necessity to look for other modes of transport that enable the population to remain in the rural setting. The solutions have been focused on developing transport systems that are as economical as possible from the energy viewpoint, through promoting transport on demand. The management of these initiatives corresponds to the municipal areas through the regional council delegations, which are normally developed through cooperation among town halls. This is the case of CABRI (Communauté d'Agglomération Briochine, agglomération de Saint-Brieuc) constituted in 2000, when 14 municipal areas joined to develop a project for sustainable development through three actions: the project of agglomeration, the pluri-annual investment plan and the agglomeration contract.

The second French example studied was the Vendôme region in the Centre of France, (activity centre with more than 10,000 jobs) where the TGV arrived in 1990. The communication to Paris in $43 \mathrm{~min}$. has promoted three poles of industrial activity specialized in the aeronautical sector (Thalès Avionics, Secan Honeywell), in the automobile sector (ZF Systèmes de direction Nacam, Rollet Productique, Thyssen Krupp Sofedit Vendôme), robotics and measurement equipment (Bourdon Haeni, Trescal and la Calhène), as well as in the domestic appliance sector (Elco Brandt). A metallurgical sector (Dargaisse, Aréméca, Sonopol, Poject and Lajoine) has also been developed around the above companies, particularly related to Thalès Avionics, Elco Brandt and Nacam France $(525,350$ and 750 jobs). The first of these companies transferred its research department from Paris with 600 jobs and the arrival of the TGV in Vendôme has led to a group of people selling their houses in Paris and establishing their main residences in this small city. This has all contributed to changing the profile of this urban nucleus, where new jobs have been created related to services for the population and commerce $(4,470$ out of the total of $10,000)$. However, unlike what was thought, the communication with the tourist zone of the Loire Castles has not worked as well as was expected.

In this region, 1990 was a key year when eleven municipal areas decided to join together in "La Communauté du Pays de Vendôme" to become the driving force of a territory made up of two urban centres and peri-urban and rural settlements. This territorial project understood the necessity to increment the 
TGV services, so representatives of the municipal areas started negotiations with the SNCF which led to the increase in the number of services between Vendôme and Paris from 40 to 70 .

Thus, in Vendôme the TGV has driven economic growth, which has necessitated the increase in the number of trains to Paris, while the organization of the transport services in the region remains to be done; there still has not been a reorganization of the TER network and systems of intermodality have not been developed to penetrate further into the region. In fact, the TGV crosses the region from north-east to south-west alongside the TER network, while a lot of territory still has no train communication and no nodes to link TGV/TER. There is not even a TER or regional bus service, and there are no combined ticket systems for both types of lines. All these factors limit the penetration of the TGV into the centre of the region, as a new organization of regional transport is necessary, in an attempt to provide systems of intermodality that increase the population mobility in these rural zones.

In this sense, the report of 2006 issued by the regional transport administration highlighted that it was necessary to organize an intermodal SNCF + VBus pass to facilitate travel of the holders to line No. 3, which communicates with the TGV station (Transports du Loir-Et-Cher [10]).

In the Rhône-Alpes region, starting from Lyon, the most important urban nucleus, there is a great relation between the TGV and the TER network, with a suitable density of lines towards the west and a clear reduction towards the east, especially after Grenoble. In the same way, the bus communications are limited to some links in the north, south and centre of the region.

\section{Experience in reorganization of transport after the arrival of the high-speed railway}

The development of the high-speed railway in France has provoked the necessity to reorganize the regional transport system. In the agglomeration of Saint-Brieuc in Brittany, diverse actions have been developed such as, for example, the Urban Transit Plan 2006-2016 in which specific actions were proposed to organize the mobility from a perspective of sustainable development and to start up a new transport model based on greater equilibrium among:

- The different transit modes with alternatives to the use of the car.

- Generations. With the aim of favouring mobility of all the inhabitants, taking into account that the car cannot be used without compromising the quality of life of future generations.

- Territories. Given that the mobility of the population does not stop at the limits of the administrative areas and access to whole transport network must be facilitated.

This model of mobility denominated "shared" is based on the cooperation among the whole set of authorities: State, Regional council, General council of the department and SNCF, with support from the different associations that participate in the project and the inclusion of the inhabitants in a "projet de partage de la mobilité" (Urban transit plan 2006-2016 [11]). This project relies 
on intermodality, combining several modes of transport throughout a journey such as, for example, bicycle plus public transport, train plus tram or metro. The most important aims of the project are to take advantage of public transport and to provide complementary services and intermodality in the railway system, urban buses and school buses.

In Brittany the planning of transport services is considered to rely on coordination among the State, the regional authorities, the local collectives and the SNCF. All of them coincide in proposing a model based on intermodality and organization of the services, given that these measures contribute to territorial cohesion, sustainable development and communication with other regions and countries (Charte du Pays de Saint Brieuc [12]).

At the same time, the urban transit plan 2007-2017 of Rennes places special importance on developing the regional trains (TER), given that this transport means is a commonly used by the inhabitants of the whole urban agglomeration. The aim is to improve the service by coordinating the bus and metro offer, utilizing a single payment service through the KorriGo card, which facilitates its use, as it can be used on both public transport means.

Furthermore, the urban projects, such as the construction of the metro, gave added benefits as they justified the creation of a public transport hub for the whole Rennes conurbation. The coach station, the bus stops, the metro and the taxi rank are around the SNCF station, so an intermodal space is created that facilitates the coordination among the different types of displacements (Direction des Infraestructures [13]). In the same way, in the city of Saint Brieuc, the arrival of the TGV spawned new urban projects in the station neighbourhood in order to site new activities and services for coordinating transport and developing intermodality.

The reorganization of the rail connections with other types of transport after the arrival of the H-SR constituted another very interesting experience in Brittany, where the Rennes conurbation planned a system of intermodality including cars, metro, trains, cycles and the bus service. To this end, four parking areas were created "Les parcs relais", in the outskirts of Rennes that allow drivers to park free and continue by metro or bus, all with the possibility of making a single payment for all the rail and bus transport.

These actions are reinforced in the town and country planning, specifically in the "Schéma de Cohérence Territoriale" (SCOT [14]), which includes a change in the transport model, to reduce the number of car journeys, increasing the public transport service or alternatives (walking, bicycle) and relating the different systems (metro, TER, bus). Thus, in Brittany, the arrival of the TGV has provoked the reorganization of transport based on intermodality, innovative transport projects and town and country planning.

This experience coupled with the Rhônes-Alpes region, where the process was initiated by the creation of the Regional Assessment of Transport, which between 2000 and 2006 studied and organized all the pertinent information. The projects were promoted by the railway infrastructure management authority in France, Réseau Ferré de Francia (RFF), to make the railway an instrument for sustainable development. The railway is an environmentally friendly transport 
mode, with a large territorial organization capacity, which values the local necessities and supports long-term economic growth. For this reason, the RFF has a priority aim of improving the quality and capacity of the train lines, financing the substitution of thermal energy TER trains with electric ones, favouring the use of the trains by all types of travellers and organizing bus and train timetables at regular intervals ( 1 or 2 hours, or $15 \mathrm{~min}$.) at all stations to facilitate use and coordination (RFF [15]).

The Rhône-Alpes region has participated in the latter initiative denominated "Cadencement" since December 2007 with a pilot project in the most in-demand zones where the efficacy has been verified in improving the TER train and bus service. This is a clear positive example of intermodality. Furthermore, this action is complemented by others such as the improvement in the services in stations, above all with the initiative of providing real-time information from 2009 and the OùRA card as a single ticketing system for the whole TER network in the Rhône-Alpes region, which can also be combined with Grenoble and Lyon's transport. It is also possible to obtain season tickets combining train-car, bus-train and car-coach-car, or even a season ticket for a service for car sharing.

In order to support the TER network and improve its services, the "Schéma Directeur Regional d'Accessibilité du Service de Transport (TER) in the Rhônes-Alpes region was approved in April 2008. This set out objectives such as creating a hierarchical network of stations and interchange hubs to ensure access to the whole region; improving the accessibility and transport service offer coordinated with different agents (associations of people with reduced mobility, rail management, RFF, SNCF, region, departments). To achieve this, reforms have been made in stations or interchanges such as the elevation of platforms or the construction of overhead walkways with lifts.

There is also a project that sets out to plan the set of transport services through a proposal approved in the regional assembly at the beginning of 2009 . This includes the reform of the stations, substitution of trains and modernization of infrastructures. To develop these actions, the "Schéma Regional des Services de Transport (SRST)" was presented in the Regional Council on the $7^{\text {th }}$ April 2008 which contains five strategic axes:

- Create a public transport network for the whole region.

- Promote complementary services and intermodality of the transport services through a network of stations, interchange hubs and intermodal tariffs.

- Create structures for cooperation and finance among the different administrations.

- Value the strategic situation in the European flows.

- Promote innovation: modernization of the services, non polluting practices, alternatives to the use of the car.

The plan dedicates special attention to the rural zones and to the tourist zones, giving support in this case to intermodal systems, favouring public transport instead of car access and encouraging the SNCF to develop the rail transport offer and modernise the TER service. To this end, an agreement was signed between the Regional Council and the SNCF on $30^{\text {th }}$ March 2007, including 
initiatives such as the service offer (intermodal travel pass, complete information in real time for passengers, ticket and pass distributers, improvement of transport vehicles, economic advantages (season tickets or travel passes at reduced prices). In Grenoble for example the waiting time for trains and buses can be consulted by "sms" in a mobile telephone. There is even an offer of transport on demand for use of the TER services, which guarantees the return transfer from the dwelling to the closest TER station.

The region gives clear support to rail transport over the car, justifying this option as the former is considered less polluting and relating it with the TER regional bus network. The "Projet de Services TER" was envisaged for this purpose, which is a project that will start in 2010, with which intermodality will be favoured throughout all the systems (bus, car, bicycle, train), augmenting the number of TER services and adapting them better to the users' necessities, in this case through the organization of timetables with regular intervals (Cadencement).

There are also projects for railway work promoted thanks to the coordination among different agents, specifically the Réseau Ferré de France, the RhôneAlpes Region, the State, The Voironnais region, the general councils of Isère and of la Drôme, the Metro and the SNCF. The "Sillon Alpin Sud" Project, focused on changing the gauge of several lines, constructing double lines in some sections and restructuring several stations is integrated in this strategy. According to the promoters of the project, this will improve the rail offer in periurban areas, decrease the duration of the journeys, develop intermodality and facilitate the access of all types of users to the stations.

These projects for reorganizing transport in France were made possible by a whole set of public actions at different levels. In the first place, the State, through the SNCF (Société Nacional de Chemins de Fer) and RFF (Réseau Ferré de France), is carrying out projects to; improve the quality and capacity of the lines, electrify the TER network, enable the access of all types of travellers, organize the train and bus timetables in regular intervals and improve the services in the stations. The following services have also been added; reservation of taxis to meet the $\mathrm{TGV}$, parking at the departure point, unification of tickets if your journey combines the plane and TGV, car hire at the destination point, which all contribute to better territorial penetration of the High-speed railway.

On the regional scale, firstly, the "Schéma de Cohérence Territoriale (SCOT)" was drawn up, providing an instrument for introducing a change in the transport model to decrease car journeys, increase the public transport systems or alternatives (walking, bicycle) and relating the different systems (metro, TER, bus). The second step, the "Schéma Régional des Services de Transport", was of vital importance, given that its aims were focused on the modernization of transport (reforming stations, substitution of trains and modernization of the infrastructures), the creation of a public transport network for the whole region and the promotion of complementary practices (stations, interchange hubs and intermodal tariff), the creation of cooperative structures for intermodal organization and promoting innovation (modernization of services, non-polluting practices and alternatives to the use of the car). Finally, the "Schéma Directeur 
Régional d'Accessibilité du Service de Transport", sets out to create a hierarchical network of stations and interchange hubs, to improve accessibility, to offer services for coordination of different agents and to carry out station and hub modernization.

On the local scale, in the definition of the urban model, the POS reserves land for dissuasory parking and intermodal public transport hubs (SNCF, bus and metro stations, taxi ranks). Moreover, the town halls are developing transit plans or mobility plans, which contemplate sustainable actions, a new transport model
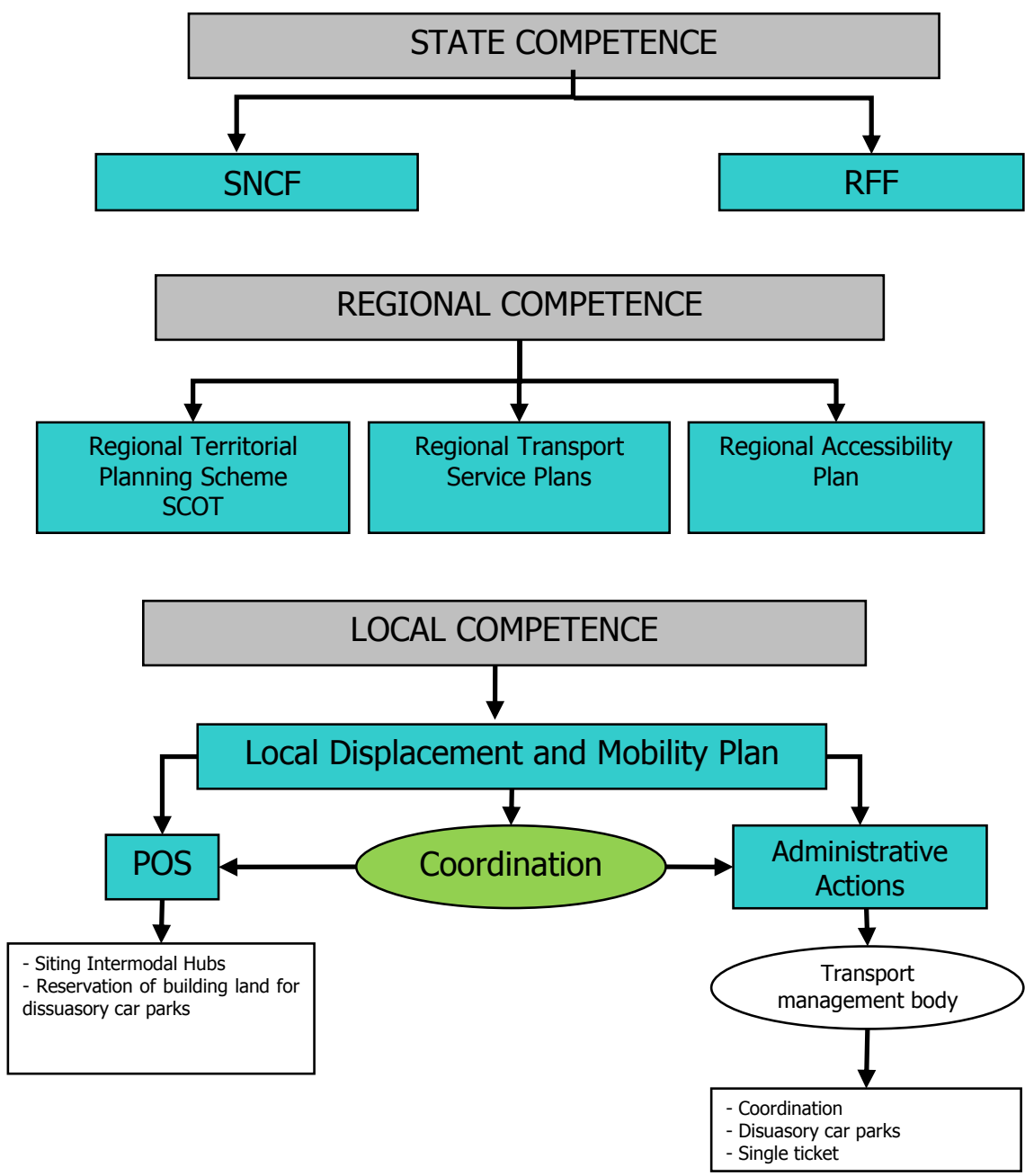

Figure 1: Scheme of distribution of state, regional and local competences related to the high-speed railway in France. 
based on a balance among the different modes, alternatives to the use of cars and access to the whole transport network. Finally, the local scale requires transport management through organisms that are dedicated to coordinating all the different modes, the parking areas "Les parcs relais" or the single ticket for all rail or bus transport. Examples of this local management are the TAL (Transport Agglomération Lyonnaise) or the TAG (Transport Agglomération de Grenoble).

\section{Some conclusions about the French experience in reorganization of transport in France}

From this study, three models can be deduced for reorganization of regional transport around the high-speed railway stations in France. In the first, the TGV crosses one extremity of the region from north-east to south-west, parallel to the TER, with no type of node connecting TGV/TER. In the second, the rail and bus network is organized from the H-S R station and penetration toward the Alps is
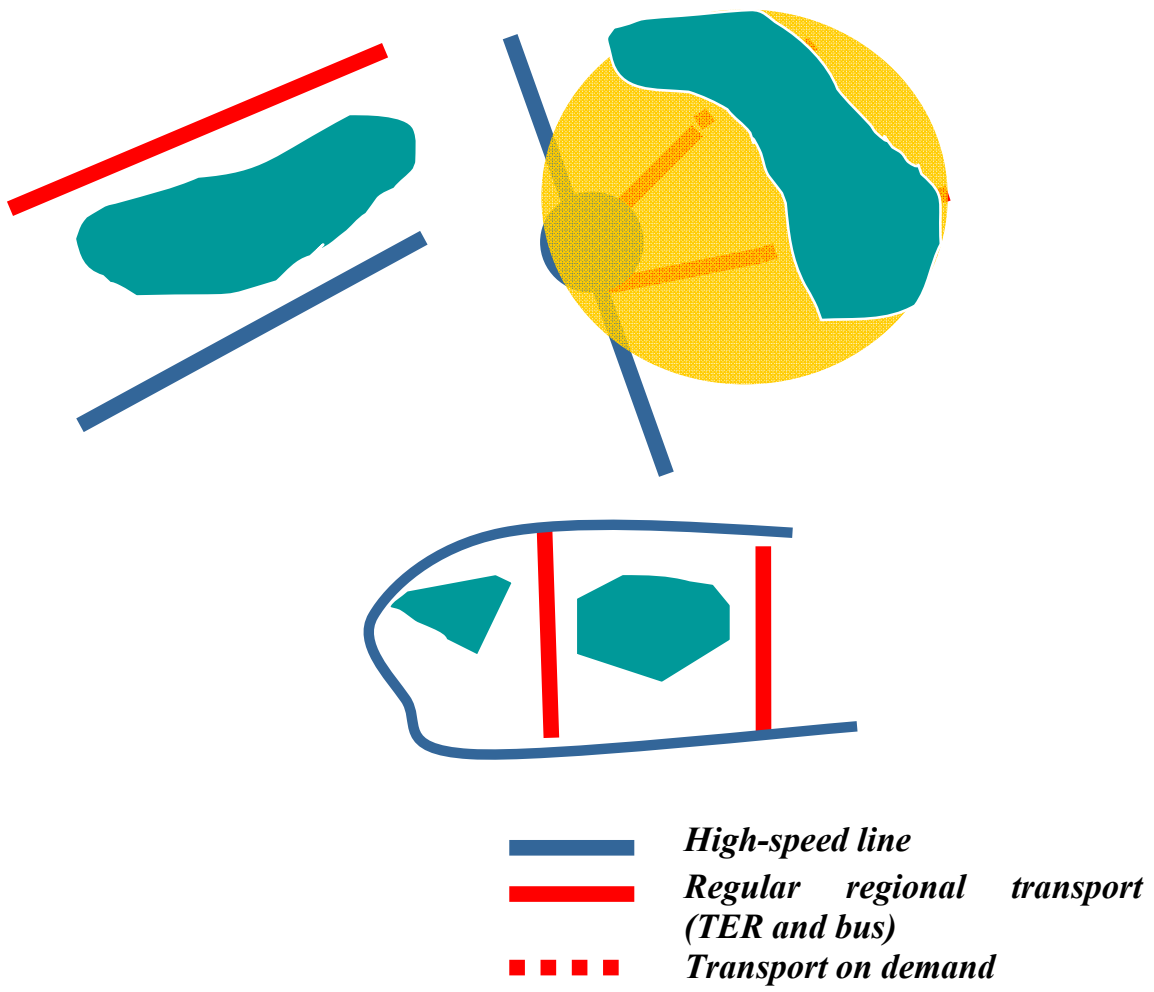

Figure 2: Reorganization models of the transport systems in Vendôme, Rhône-Alpes and Brittany. Compiled by the authors (2010). 
achieved by bus and on-demand transport. In the third, the model is organized through the coastal H-S R complemented by regional railway lines (TER) toward inland area and bus routes.

In this way, the models range from the model of a regional service parallel to the high-speed one (Vêndome case), through the radial model of Rhône-Alpes, which has hardly any users in the ends of the branches of the service, to the Brittany regional model, where the regional bus and rail service runs in parallel, linking parts of the rail network, but leaving some interstitial areas without services. In all cases, the reorganization of the local transport system is necessary, through the creation of suitable routes and coordination of the timetables of regional services with high-speed ones.

Finally, the areas of low population density with no ordinary transport require the organization of transport on demand systems that, through very specific actions, connect these areas to the new station. Among the specific actions to be undertaken to implement this type of systems on a regional scale is the organization of flexible routes, combining distinct destinations and users, with suitable reservation systems. These systems will be organized using information technology methods, coordinated with timetables of the high-speed service and they will require vehicles with a very small capacity, such as taxis or microbuses. The coordination of these flexible services with the ordinary regional transport ones is a necessary part of the regional transport reorganization to accommodate the arrival of the high-speed train and it is the only way of guaranteeing access to the new infrastructure for the inhabitants of low population density zones within a region.

\section{References}

[1] Ribalaygua, C and Ureña, J.M., Les villes espagnoles saisies par la grande vitesse ferroviaire: stratégies et projet (Chapter 2). Mobilité et écologie urbaine. Ed. Descartes \& Cie : Paris, 2008

[2] Ureña, J.M., et al, Alta Velocidad ferroviaria e integración metropolitana en España: el caso de Ciudad Real y Puertollano, EURE, XXXII, 92, pp. 87104,2005

[3] De Meer, A., Alta velocidad, intermodalidad y territorio, Research project financed by Ministry of Public Works: Santander, 2008

[4] AAVV (2005) Monografía “Alta velocidad en el transporte", Ingeniería y Territorio, $\mathrm{n}^{\mathrm{o}} 70$.

[5] Bellet, C., Los efectos socioeconómicos y territoriales del tren de alta velocidad en Segovia. Caja Segovia: Segovia, 2008

[6] Garmendia, M. et al., Urban residential development in isolated small cities that are partially integrated in metropolitan areas by high speed train. European Urban and Regional Studies, 15 (3), pp. 249-264, 2008

[7] Rodríguez Bugarín, M.; Novales Ordax, M.; Orro Arcay, A. "Alta velocidad y territorio. Algunas experiencias internacionales". Ingeniería y Territorio, $\mathrm{n}^{\mathrm{o}} 70,2005, \mathrm{n}^{\mathrm{o}} 70$, pp. 9 . 
[8] Ribalaygua, C; De Meer, A, "Rural areas, high Speed train accessibility and sustainable development". Sustainable Development and Planning I, edit Wit Press, Southampton, Boston , ISBN 978-1-84564-424-6, pp 375389,2009

[9] Rennes Métropole, Plan de déplacements Urbains 2007-2017, 2007

[10] Transports du Loir-et-Cher. Rapport d'activité de l'exploitant : stdlc, 2006

[11] CABRI agglomération de Saint Brieuc, Plan de déplacements urbains 2006-2016, 2006

[12] Charte du Pays de Saint Brieuc, 2001, pp 47

[13] Direction des Infraestructures. Quand le métro embellit la ville, Ville de Rennes, 2002.

[14] SCOT du Pays de Saint Brieuc, 2007

[15] RFF (Réseau Ferré de France), Le développement et l'aménagement durables sur les rails, 2007 